\title{
Candi Prambanan: Pengelolaan Dan Potensi Persoalannya
}

\section{Sugeng Riyanto}

Keywords: public archaeology, cultural resource management, risk map, protection, utilization, conservation

\section{How to Cite:}

Riyanto, S. (2007). Candi Prambanan: Pengelolaan Dan Potensi Persoalannya. Berkala Arkeologi, 27(2), 66-80. https://doi.org/10.30883/jba.v27i2.953

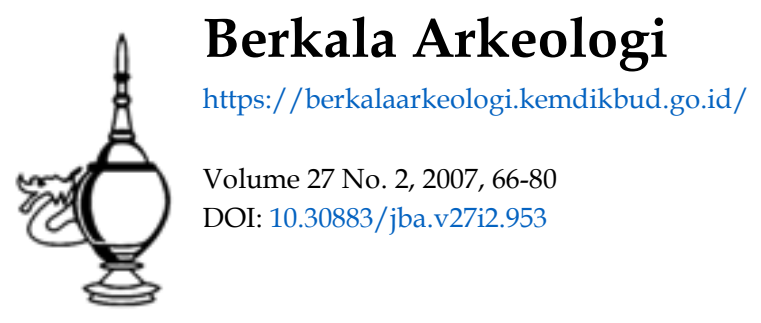

\section{cc) (1)(2)}

This work is licensed under a Creative Commons Attribution-NonCommercial-ShareAlike 4.0 International License. 


\title{
CANDI PRAMBANAN: PENGELOLAAN DAN POTENSI PERSOALANNYA
}

\author{
Sugeng Riyanto \\ (Balai Arkeologi Yogyakarta)
}

\begin{abstract}
Pendahuluan
Candi Prambanan adalah salah satu sumberdaya arkeologi yang dimanfaatkan sebagai objek wisata. Dalam batas tertentu, pemanfaatan secara ekonomik ini merupakan salah satu dari tiga pemanfaatan, di samping manfaat akademik dan ideologik (Cleere, 1989: 10). Di sisi lain, pemanfaatan ekonomik dengan pengelola tunggal PT Taman berpotensi memunculkan berbagai persoalan yang semestinya dikaji secara khusus. Makalah ini merupakan paparan perjalanan Candi Prambanan dari saat "ditemukan" hingga kini dengan berbagai balutan potensi persoalannya.
\end{abstract}

Sasaran paparan ini adalah memberi gambaran kondisi dan potensi persoalan sebagai salah satu landasan dalam pendekatan, analisis, maupun penyusunan konsep guna mengurangi potensi persoalan dan meningkatkan potensi sumberdaya arkeologi dan lingkungannya bagi kepentingan yang lebih luas.

\section{Lorong Waktu Candi Prambanan}

\subsection{Riwayat Penemuan Situs Candi Prambanan}

Candi Prambanan yang juga dikenal dengan nama Candi Lara Jonggrang secara astronomis terletak pada koordinat $110^{\circ} 29^{\prime} 36^{\prime \prime}$ BT dan $7^{\circ} 45^{\prime} 18^{\prime \prime}$ LS. Secara administratif, candi ini terletak di Desa Karangasem, Kecamatan Prambanan, Kabupaten Sleman, Daerah Istimewa Yogyakarta, tepatnya di sebelah utara ruas jalan Yogyakarta Solo.

Catatan harian C.A. Lons yang dibuat pada tahun 1733 hingga kini dianggap sebagai awal ditemukannya situs Candi Prambanan. Dia adalah salah seorang pegawai VOC yang bertugas di Semarang dan sempat 
mengunjungi situs ini dalam perjalanannya meninjau peninggalan purbakala di Kartasura dan Yogyakarta, termasuk di antaranya adalah Candi Kalasan, Candi Sari, dan Candi Sewụ. (Santiko, 1992: 1).

Sejak itu, Candi Prambanan mendapat perhatian khusus terutama dari pemerintah kolonial, meskipun belum cukup besar. Berdasarkan laporan yang diterima, akhirnya pada tahun 1746 Gubernur Jenderal van Imhoff juga mengunjungi situs ini (Santiko, 1992: 2).

Selama hampir tiga tahun, yaitu pada tahun 1805 hingga 1807 sebuah kegiatan yang sistematis dilaksanakan di sini. Kegiatan tersebut adalah pengukuran luas kompleks situs yang dilaksanakan oleh H.C. Cornelius, seorang opsir geni tentara Belanda, atas perintah Gubernur Engelhard. Pengukuran yang dilakukan oleh Cornelius meskipun dianggap kurang akurat namun menjadi awal bagi kegiatan selanjutnya yang lebih sistematis. Pengukuran yang lebih akurat dan sistematis dilakukan oleh Mackenzie yang ditugasi oleh Gubernur Jenderal Stamford Raffles. Apa yang diperoleh dari hasil pengkuran Mackenzie ini kemudian menjadi landasan dalam penanganan temuan ini oleh Brumund (Santiko, 1992: 3).

\subsection{Riwayat Pemugaran Candi Prambanan}

\subsubsection{Masa Kolonial}

"Kembalikanlah istanaku, yang tak ada bandingnya itu, kepada kemegahan yang lama. Binalah kembali Candi Prambanan ini". Kalimat rekaan Kempers seolah benar-benar mewakili Loro Jonggrang dalam legenda; bagaikan ajakan untuk mengembalikan kemegahan bangunan Candi Lorojonggrang yang runtuh dan terbengkelai selama beratus-ratus tahun lamanya. Dalam pandangan Kempers, kondisi Candi Prambanan pada waktu itu yang sangat menyedihkan juga merupakan gambaran kesedihan Loro Jonggrang, yang menunggu untuk dipinang kembali (Kempers, 1985: 31-32).

Pada tahun 1885 peminang pertama pun datang. Dia adalah Ir. J.W. ljzerman, ketua Archaeologische Vereeninging di Yogyakarta (Kempers, 1985: 32; Santiko, 1992: 3). Langkah pertama yang dilakukannya adalah melakukan pembersihan seluruh bangunan dari tanah dan tumbuhan yang menutup sebagian besar bangunan-bangunan di kompleks candi ini. 
Usaha ljzerman kemudian dilanjutkan oleh J. Groneman yang dilengkapi dengan foto-foto hasil karya Chepas, khususnya relief Candi Çiwa. Namun demikian, kegiatan Groenman belum dilakukan secara sistematis sehingga sukar dalam upaya pemugaran selanjutnya (Santiko, 1992: 4; Haryono dkk., 2004: 35).

Van Erp pada tahun 1902 - 1903 memanfaatkan hasil usaha ljzerman untuk menyelamatkan bilik-bilik penampil Candi Çiwa dengan cara mengembalikan runtuhan batu-batu ke tempat aslinya. Di samping itu, dia juga mulai memperhatikan seni hias dan teknik bangunan Candi Prambanan serta membandingkannya dengan banguna candi lainnya di Jawa Tengah (Santiko, 1992: 5; Haryono, dkk., 2004: 35).

Pada tahun 1915 relief-relief difoto ulang oleh van Stein Callenfels dan dibantu oleh Poerbatjaraka sebagai bahan dokumentasi yang lengkap serta sebagai bahan penyelidikan identifikasi bangunan candi. Dengan bantuan Poerbatjaraka, relief-relief di Candi Wisnu dapat diidentifikasi sebagai cerita Kresnayana. Demikian pula dengan relief di pagar langkan bagian dalam Candi Çiwa yang berhasil diidentifikasi oleh Poerbatjarakan sebagai cerita Ramayana (Santiko, 1992: 6; Haryono, dkk., 2004: 35).

Tahun 1918 adalah awal pemugaran Candi Prambanan yang dilakukan secara sistematis. Pada saat itu, FDK Bosch menugaskan P.J. Perquin di bawah Oudheidkundig Dienst untuk menyusun kembali Candi Çiwa (Sam, 1950: 2; Santiko, 1992: 6; Ibrahim, 1996: 41; Haryono 2004: 35-36).

Pekerjaan Perquin kemudian dilanjutkan oleh De Haan dengan membuat susunan percobaan hingga pelipit kaki Candi Çiwa (Sam, 1950: 3; Santiko, 1992: 6; Ibrahim, 1996: 41; Haryono 2004: 36).

Mulai tahun 1935 tugas pemugaran diberikan kepada P.V. van Romondt, seorang arsitek yang juga mempelajari sejarah kesenian. Dalam melaksanakan tugasnya, van Romondt dibantu oleh P.H. Van Coolwijk serta dua orang Indonesia, yaitu Soehamir dan Samingun (Santiko, 1992: 6-7; Ibrahim, 1996: 41; Haryono, dkk.; 2004: 6). 
Pada tahun 1942 Hindia Belanda menyerah kepada Jepang, dan pegawaipegawainya menjadi tawanan sehingga pekerjaan pemugaran dilajutkan oleh putra Indonesia, yaitu Soehamir yang dibantu oleh Samingun dan Soewarno berhasil menenyelesaikan pembinaan hingga pelipit puncak candi.

Pada saat rakyat Indonesia mengumumkan kemerdekaan, 17 Agustus 1945, pembangunan Candi Çiwa telah mencapai tinggi 32,50 m. (Sam, 1950: 4).

\subsubsection{Pasca Kemerdekaan}

Pada masa revolusi, pemugaran bukan hanya terhenti, akan tetapi yang lebih parah adalah dokumen dan arsip-arsip penting lainnya sebagian musnah akibat perang. Pada waktu aksi militer ke-2 (19 Desember 1948) pemugaran baru mencapai pertengahan badan tingkat atap yang ke-4, setinggi sekitar 35,25 meter (Sam, 1950: 5; Ibrahim, 1996: 41).

Pada tanggal 6 Juni 1949 kegiatan pemugaran dimulai lagi oleh Bagian Purbakala, Djawatan Kebudajaan RI, dan hingga tahun 1950 telah mencapai tinggi 37,25 meter (Sam, 1950: 6). Pada tahun 1953, dengan terpasangnya puncak atap candi Çiwa, maka pemugaran Candi Çiwa dinyatakan selesai dan kemudian diresmikan oleh Presiden Soekarno pada tanggal 20 Desember 1953 (Santiko, 1992: 8; Ibrahim, 1996: 41; Haryono 2004: 36).

Pada tahun 1951, sebenarnya telah dilakukan susunan percobaan pada candi Brahma dan Candi Wisnu, namun kegiatan pemugaran terhenti hingga tahun 1977 ketika Th. Aq. Soenarto memimpin pemugaran Candi Brahma (SPSP DIY, 1987; Ibarhim 1996: 41-43).

Pemugaran Candi Wisnu secara fisik baru dimulai pada tahun 1982 dan dilakukan dalam sembilan tahap.

Pengelolaan situs Candi Prambanan baik penelitian maupun pemugaran yang terus berlangsung antara lain menghasilkan gambaran bahwa kompleks candi ini terbagi menjadi tiga halaman, yaitu halaman luar, halaman tengah, dan halaman pusat. Halaman pusat terdiri atas beberapa kelompok bangunan yang meliputi: 
1. Kelompok candi utama yaitu Candi Çiva, Candi Brahma, dan Candi Vishnu

2. Kelompok candi vahana, yang terdiri atas tiga bangunan, yaitu Candi Nandi, Candi A, dan Candi B

3. Kelompok candi apit terdiri atas dua bangunan yang mengapit tiga candi utama dan candi vahana. Kedua candi apit ini letaknya saling berhadapan satu sama lain.

4. Kelompok candi kelir, berjumlah empat bangunan yang masing-masing terletak di pintu masuk hàlaman pertama.

5. Kelompok candi sudut, terdiri atas empat bangunan yang masingmasing terletak di keempat sudut halaman pertama.(Subroto, 1993: 4-5).

Mulai tahun 1991, pengelolaan situs Candi Prambanan diarahkan pada pemugaran kelompok candi wahana dan berakhir pada tahun 1993. Pelaksanaan pemugaran tersebut secara eksplisit juga dilandasi dengan nilai kemanfaatan, yaitu: nilai informatif, nilai estetis, nilai asosiatif, dan nilai wisata (Subroto, 1993: 14).

\section{Pengelolaan Candi Prambanan}

\subsection{Pelestarian}

Pelestarian candi-candi di kawasan Prambanan merupakan tanggung jawab UPT (Unit Pelaksana Teknis) di bawah Direktorat Jenderal Sejarah Dan Purbakala pada Departemen Kebudayaan dan Pariwisata. Instansi ini dulu bernama Suaka Peninggalan Sejarah Dan Purbakala (SPSP) dan sejak Tahun 2002 berganti nama menjadi Balai Pelestarian Peninggalan Purbakala (BP3). Uraian singkat mengenai UPT ini dalah sebagai berikut (Setyastuti 2005: 58-66)

Tugas pokok dan fungsi BP 3 adalah melakukan pelestarian peninggalan sejarah dan purbakala. Dalam upaya pelestarian tersebut meliputi beberapa kegiatan, yaitu : Perlindungan, pemeliharaan, pemugaran, dokumentasi, dan publikasi. 
Dalam melaksanakan fungsi dan tugas pelestarian tersebut, BP 3 mempunyai Kantor Unit yang fungsi dan tugasnya mengelola pelestarian tiap-tiap kompleks percandian. Sesuai dengan batas wilayah administratif candi-candi di kawasan Prambanan, BP 3 DIY mempunyai Kantor Unit Candi Prambanan yang mengelola pelestarian Candi Prambanan. Sedangkan BP 3 Jawa Tengah mempunyai Kantor Unit Candi Sewu yang mengelola Candi Sewu, Lumbung, dan Bubrah. Sedangkan Candi Plaosan dan Candi Sojiwan, pengelolaannya tidak dilakukan oleh Kantor Unit tersendiri, tetapi langsung dikelola oleh BP 3 Jawa Tengah, di bawah Sub.Seksi Pemugaran. Adapun struktur organisasi Kantor Unit BP 3 adalah sebagai berikut.

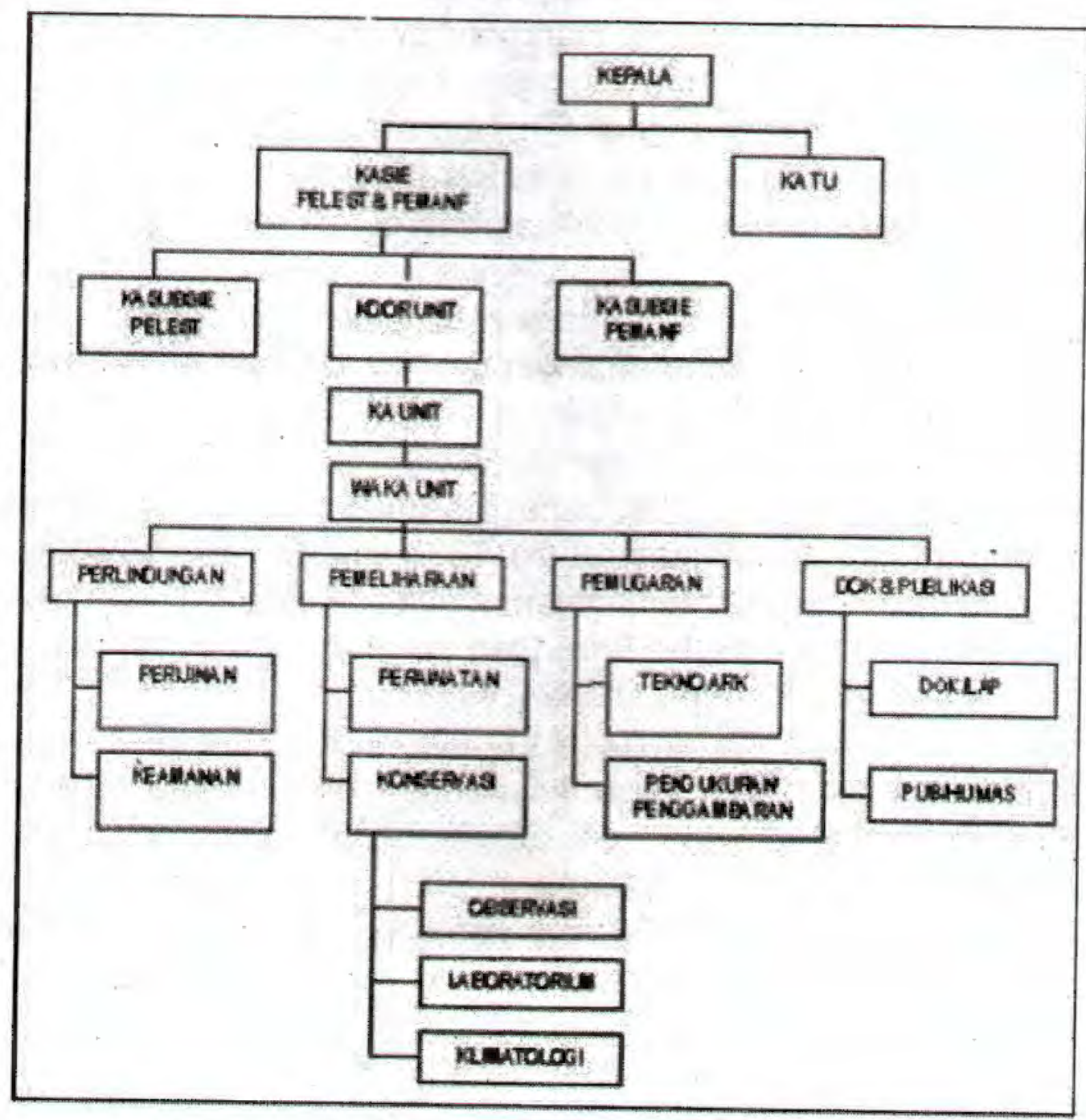

Strukar Kelembagaan BP3 
Kegiatan pelestarian yang dilakukan terhadap candi-candi di Kawasan Prambanan oleh BP3 meliputi kegiatan pokok yang berkaitan dengan pelestarian, yaitu perlindungan, pemeliharaan, dan pemugaran.

\subsection{Kompleks Candi Prambanan sebagai Objek Wisata}

Secara resmi, situs Candi Prambanan dikelola sebagai objek wisata sejak tahun 1980. Secara yuridis Candi Prambanan dan Borobudur dikelola sebagai objek wisata oleh PT Taman Wisata Candi Borobudur dan Prambanan berdasarkan Akte Notaris: Soeleman Ardjasasmita, S.H. Nomor 19 tanggal 15 Juli 1980. Kemudian pada tahun 1992 kewenangan pengelolaan didukung dengan Keppres Nomor: 1 tahun 1992 tanggal 2 Januari 1992. Dalam perkembangannya, kawasan Ratu Boko pada tahun 1994 dijadikan sebagai bagian dari pengelolaan Taman Wisata dan secara yuridis berganti nama menjadi PT Taman Wisata Candi Borobudur, Prambanan dan Ratu Boko berdasarkan Akta Notaris: Soekaimi, S.H. Nomor: 15 tanggal 3 Agustus 1994 (Soebiarso, 2003: 3).

Riwayat keberadaan PT Taman sebenarnya mengemban tugas mulia terutama dalam konsep dasar sebagaimana diuraikan oleh Setyastuti (2005: 67) sebagai berikut. Sebagai pengelolan Candi Prambanan sebagai objek wisata, kebreadaan PT Taman Wisata tidak terlepas dari Proyek Pembangunan Taman Wisata Candi Borobudur dan Prambanan yang dikembangkan pada sekitar tahun 1070-an. Candi Borobudur dan Prambanan dikembangkan sebagai objek wisata melalui serangkaian studi sejak tahun 1973 hingga 1979 dengan bantuan teknis dari pemerintah Jepang. Studi ini melalui tiga tahapan, yaitu :

1. Regional Master Plan Studi pada tahun 1973 - 1974 yang merupakan studi pengembangan kepariwisataan dalam skala regional dan mencakup dua wilayah, yaitu Jawa Tengah dan Daerah Istimewa Yogyakarta. Studi ini dilakukan oleh The Overseas Technical Cooperation Agency (OTCA) dan di dalamnya termasuk studi tentang Proyek Taman Purbakala Borobudur, Prambanan, dan Dieng.

2. Project Feasibility Study pada tahun 1975 - 1976, yaitu studi untuk menyusun Rencana Induk (Master Plan) Taman Purbakala Nasional Borobudur dan Prambanan. Studi ini dilakukan oleh sebuah Tim dari 


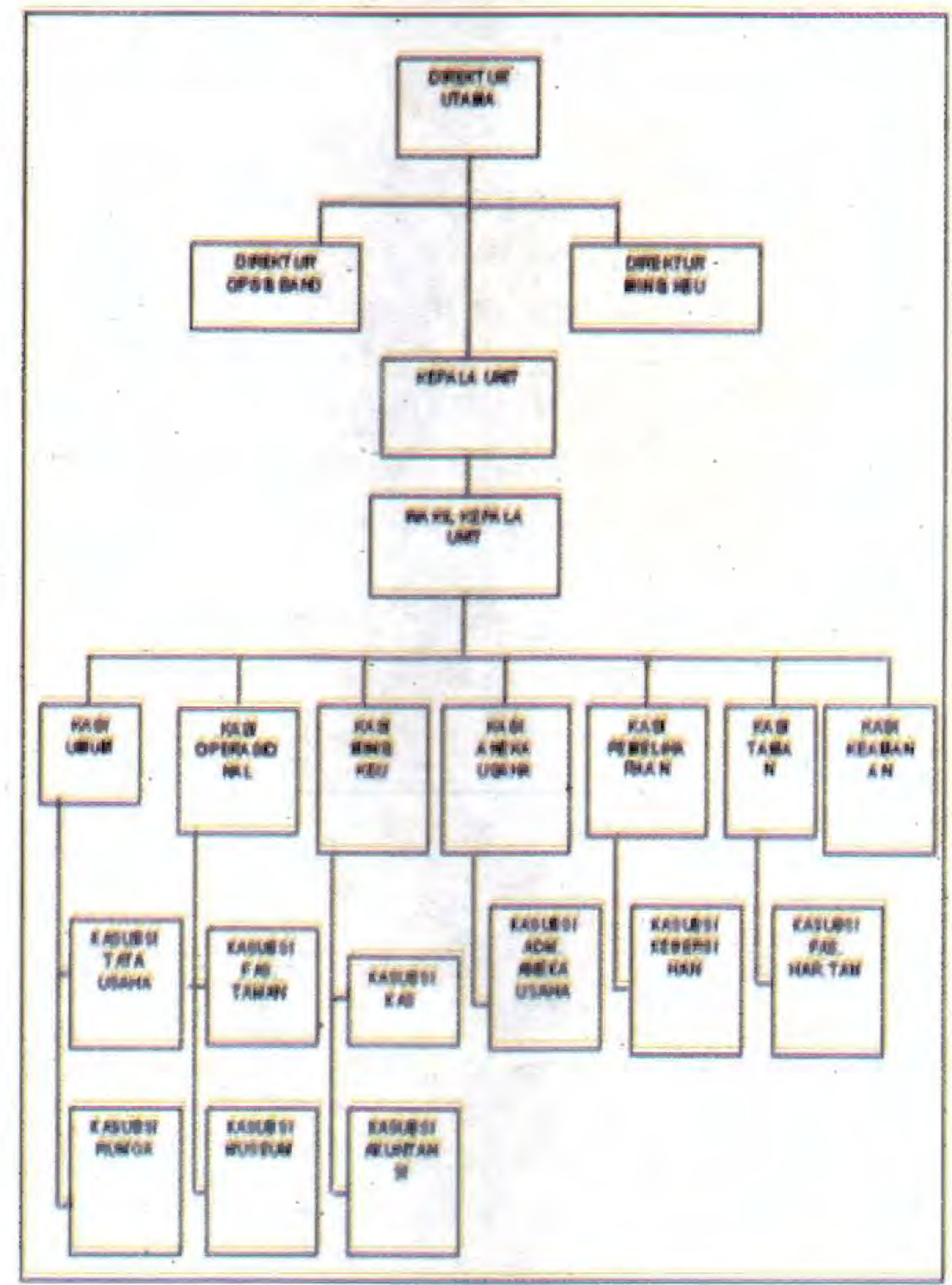

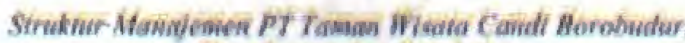
Pranhaman dan Romboks

Japan International Cooperation Agency (JICA) bersama Tim dari Indonesia. Sasaran dalam studi ini adalah konsep-konsep yang menyeluruh berkenaan pengembangan taman purbakala.

3. Review tahun 1977 - 1979 yang juga meliputi studi sosial ekonomi di area taman.

Dalam studi tersebut dihasil tiga konsep dasar pengembangan Taman Wisata yang menjadi landasan operasinal dan pengembangan aspekk lain 
yang terkait. Ketiga konsep dasar dimaksud adalah : 1) Taman secara permanen diperuntukkan bagi pelestarian monumen candi, 2) Sebagai pusat penelitian arkeologi di Indonesia, 3) Pusat pendidikan generasi muda

Sebenarnya perusahaan ini juga mengemban misi yang lebih luhur, yaitu menunjang pelestairian warisan budaya bangsa di samping mengembangkan kegiatan usaha kepariwisataan. Secara lebih eksplisit misi ini dituangkan ke dalam kegiatan usaha, yang salah satunya adalah mengelola peninggalan sejarah dan purbakala termasuk kegiatan teknis pemeliharaan dan pengawasan lingkungannya (PT Taman Wisata CBPRb, tt.: 6).

\section{Stakeholders di Candi Prambanan}

Stakeholders sebelum Candi Prambanan menjadi objek wisata relatif terbatas, yaitu meliputi Pemerintah Belanda (khususnya OD) dan Pemerintah RI (Bagian Purbakala, Djawatan Kebudajaan hingga SPSP). Setelah Candi Prambanan menjadi objek wisata utama yang dikelola oleh PT Taman, muncul hampir berbareng stakeholders baru, antara lain:

- Dari kalangan pemerintah, meliputi Pemda Klaten dan struktur di bawahnya (Jawa Tengah), Pemda Sleman dan struktur di bawahnya (DIY)

- Instansi Pelestarian, meliputi BP3 DIY dan BP3 Jawa Tengah

- Kalangan akademik, meliputi Balai Arkeologi dan Perguruan Tinggi

- Kalangan dunia usaha, meliputi pengusaha hotel, restoran, biro perjalanan

- Unsur masyarakat, meliputi LSM (antara lain Jogja Heritge Society dan Paguyuban Peduli Budaya Jawa), pedagang kaki lima dan asongan, juru parkir, guide, dsb.

- Konsumen, meliputi wisatawan nusantara dan wisatawan manca Negara.

Tumbuhnya stakeholders baru dalam banyak hal dipengaruhi oleh pengelolaan Candi Prambanan sebagai objek wisata. Dalam banyak hal pula pengelolaan ini didominasi oleh PT Taman, sebagaimana terlihat pada gambar berikut ini (Setyastuti, 2005). 


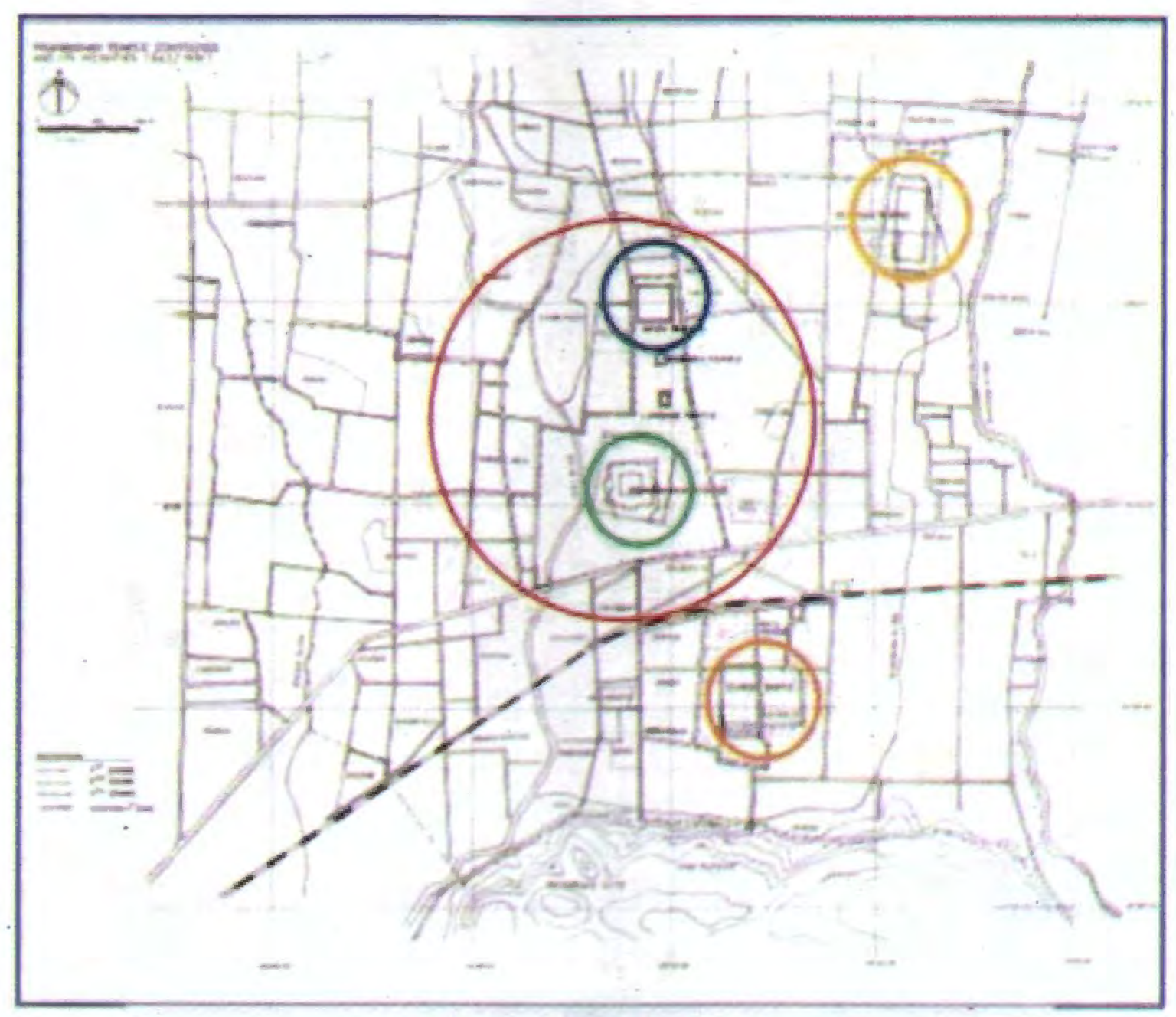

Bok pengelolaan obyek wisata

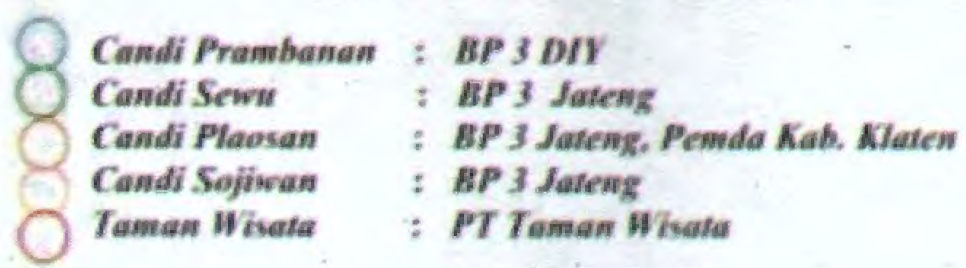

Sementara itu, gambaran pengelolaan kepariwisataan oleh PT Taman adalah sebagai berikut (Setyastuti, 2005):

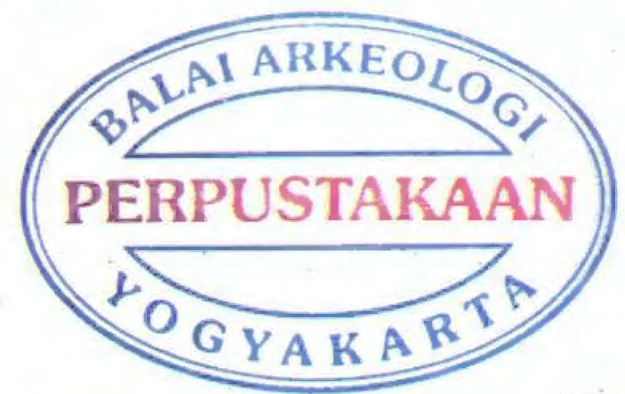




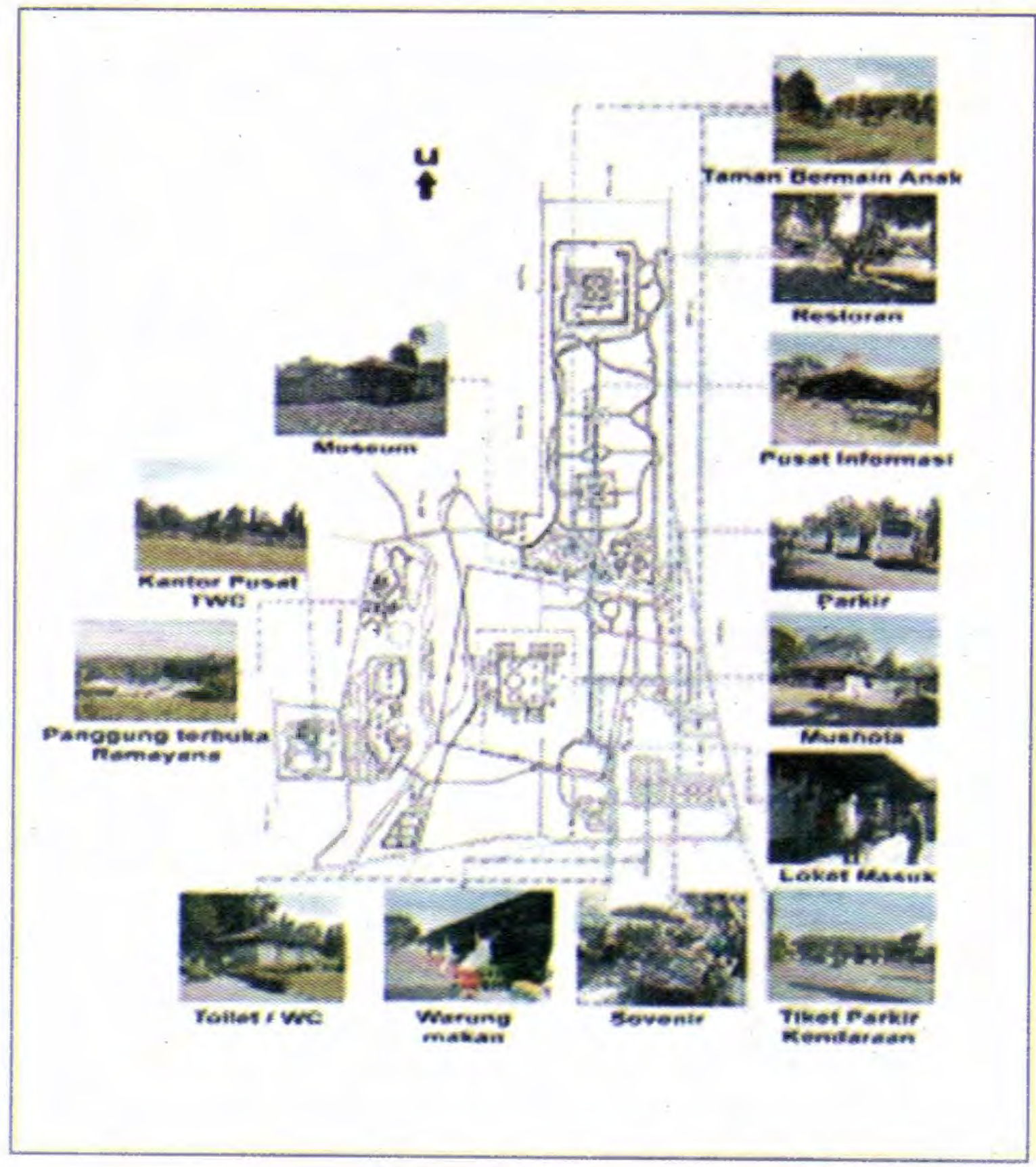

\section{Potensi Persoalan dan sasaran Ideal*}

Munculnya stakeholders bersamaan dengan keberadaan PT Taman dalam batas tertentu dipandang sebagai potensi munculnya berbagai persoalan pengelolaz kawasan Candi Prambanan. Secara umum, potensi persoalan tersebut meliputi beberapa aspek sebagai berikut. 


\subsection{Aspek Pelestarian BCB}

Potensi persoalan dalam aspek ini terbagi dalam dua kategori, yaitu 1) kategori beban pembiayaan konservasi sebagai konsekwensi logis ketika BCB "dijual", dan 2) kategori beban fisik bangunan akibat penerapan strategi mass tourism. Sasaran ideal dari potensi persoalan pada aspek ini adalah pariwisata yang berwawasan pelestarian.

\subsection{Aspek Penelitian dan Pendidikan}

Potensi persoalan dalam aspek ini meliputi: 1) akses terhadap situs yang telah dibagi dalam beberapa blok pengelolaan dengan dominasi PT Taman, 2) ketersediaan data dan informasi akademik. Sasaran ideal dalam aspek ini adalah kemudahan akses dan ketersediaan data dan informasi bagi kalangan akademik.

\subsection{Aspek Peluang Usaha dan Pekerjaan}

Aspek ini meliputi dua kategori, yaitu 1) peluang usaha dan pekerjaan di lokasi Taman yang meliputi perparkiran, pedagang, dan pramuwisata; serta 2) peluang usaha dan pekerjaan di luar lokasi Taman, yang meliputi hotel, restoran, dan biro perjalanan. Sasaran ideal dalam aspek ini adalah keberdayaan masyarakat ocal dalam kepariwisataan di kawasan Prambanan.

\section{4.. Aspek Pelayanan Kunjungan}

Pelayanan kunjungan merupakan titik paling strategis dalam pengelolaan Candi Pramaban secara umum. Hal ini antara lain meliputi: ticketing, pelayanan informasi dan pendidikan ublic, jalur kunjungan, fasilitas, kenyamanan, keamanan, dsb. Sasaran ideal dalam aspek ini meliputi terpenuhinya harapan, keinginan, dan kebutuhan pengunjung atas kunjungan di Candi Prambanan, baik dalam hal fasilitas maupun informasi.

\subsection{Dampak Sosial-Budaya}

Baik positif maupun negatif, dampak sosial dan budaya bagi masyarakat di sekitar kawasan wisata Taman tentu muncul, sehingga hal ini perlu menjadi perhatian tersendiri. Dampak ini terutama diakibatkan oleh dua 
hal, yaitu 1) keragaman pengunjung yang meliputi berbagai status sosial dan berbagai latar belekang budaya, dan 2) perubahan kondisi lingkungan dengan adanya Taman Wisata dengan berbagai fasilitas pendukungnya. Dalam hal ini, sasaran idealnya adalah mengurangi dampak negatif dan meningkatkan dampak positif khususnya untuk masyarakat lokal maupun pengunjung.

\section{Penutup}

Paparan ini sama sekali belum selesai, karena langkah lanjutnya justru yang paling menentukan, yaitu keberanian untuk mendekati potensi persoalan itu. Hal ini berguna untuk menyusun konsep operasional agar potensi persoalan tereliminasi dan berbuah potensi ideal dalam keselarasan kepentingan beragam stakeholders.

"Kembalikanlah istanaku, yang tak ada bandingnya itu, kepada kemegahan yang lama. Binalah kembali Candi Prambanan ini". Tidak mustahil akan muncul peminang Loro Jonggrang berikutnya yang mampu memenuhi permintaan "Loro Jonggrang" tersebut. Masalahnya adalah, "bagaimana?".

Dalam teori arkeologi modern bermunculan berbagai pandangan bagaimana arkeolog tidak cukup hanya mengetahui masa lalu saja, tetapi sudah saatnya menghadirkan masa lalu di masa kini beserta berbagai muatan makna hingga berguna pula bagi masa kini. Untuk itulah berbagai kerangka dan teori baik berkenaan dengan Arkeologi Publik, kerangka CRM, pandangan "Post Processual", perundang-undangan, bahkan analisis khusus, seperti pengelolaan konflik pun dapat digunakan sebagai alat dan cara untuk menjawab "bagaimana" tadi. Dengan cara itu lah barangkali Loro Jonggrang dapat dipinang. 


\section{KEPUSTAKAAN}

Cleere, Henry. 1989. "Introduction: The Rationale of Archaeological Heritage Management". Henry F. Cleere (ed.) Archaeological Heritage Management in the Modern World. London: Unwin Hyman. HIm. 1-19.

Haryono, Timbul, dkk. 2004. Pelapukan Batu Candi Siwa Prambanan dan Upaya Penanganannya. Yogyakarta: BP3 Yogyakarta.

Ibrahim, Maulana. 1996. Kompleks Candi Prambanan Dari Masa ke Masa. Jakarta: Direktorat Perlindungan dan Pembinaan Peninggalan Sejarah dan Purbakala.

Kempers, A.J. Bernet. 1985. "Pembinaan Kembali Candi Prambanan, Menyambut Tercapainya Puncak Candi Prambanan". Amerta, No. 1, cetakan ke-2. Jakarta: Proyek Penelitian Purbakala Jakarta, Departemen Pendidikan dan Kebudayaan, p.p. 30-37.

PT Taman Wisata Candi Borobudur, Pramabanan, Ratu Boko.t.t. Komitmen Pengelolaan Warisan Budaya Bangsa.

Sam, S. 1950. Riwayat Singkat Pembangunan Tjandi Çiwa Prambanan (Percandian Lara Djonggrang). Jakarta: Kementrian P.P dan K. Djawatan Kebudajaan.

Santiko, Hariani. 1992. Candi Prambanan; Deskripsi, Latar Belakang Agama dan Masa Pendidirannya. Laporan Penelitian. Jakarta: Fakultas Sastra Universitas Indonesia.

Setyastuti, Ari. 2005. Evaluasi Kebijakan Pengelolaan Candi-candi di Kawasan Prambanan (Analisis Berdasarkan Pendekatan Pengembangan Paniwisata yang Berkelanjutan). Tesis. Yogyakarta: Magister Pariwisata Program Pascasarjana UGM. 
Soebiarso, Wagiman. 2003. Pemanfaatan Candi Prambanan sebagai Obyek Wisata Budaya. Makalah disampaikan dalam rangka Rapat Koordinasi Pelestarian Candi Prambanan sebagai Warisan Budaya Dunia di Prambanan, Yogyakarta, 10-11 September 2003.

Suaka Peninggalan Sejarah dan Purbakala. 1977-1987. Pemugaran Candi Brahma Prambanan. Laporan Pelaksanaan. SPSP DIY.

Subroto, Ph., dkk. 1993. Candi Wahana, Pelestarian dan Pemanfaatan. Yogyakarta: Panitia Pemugaran Candi Wahana Candi Rara Jonggrang Prambanan. Direktorat Jenderal Kebudayaan, Departemen Pendidikan dan Kebudayaan.

*) Potensi persoalan ini merupakan potensi yang mengemuka sebelum peristiwa gempa 27 Mei 2006 